\title{
The Interaction between Service Quality and Students Satisfaction
}

\author{
Sheikh Aftab Ahmad \\ University of Hail, Hail, Saudi Arabia \\ aftab_ahmad@hotmail.co.uk
}

\begin{abstract}
This study aim to describe the effect of service quality on students' satisfaction. Study used a sample of respondents from university students in Hail, Saudi Arabia and the data were collected through questionnaire. Descriptive and regression analysis were used to find out the relationship between students satisfaction and service quality. This study concluded that there is a significant effect of tangible, reliability on students' satisfaction at university in Hail state. Moreover, there is a difference in service quality of higher educations managed by goverment and those managed by a foundation (private). Also, there is a difference between students satisfaction in public and private universities. Based on the findings, it is suggested that the goverment needs to pay more attention to increase service quality for the satisfaction of students, which will develop the public interest to go to university.
\end{abstract}

Keywords: Reliability, Tangible, Responsiveness, Insurance, Empathy

\section{Introduction}

The existence of higher education is strongly influenced by the internal and external developments of organization. The internal development is colored bythe potential of educational inputand itsprocess such as the potential of students, lecturer quality and working ethos. The external development is much more colored by the changes in economic, social, technology and culture which in turn becomes a mirror and demands of society in common. As a sub-system of national development, the education, especially higher education, must support national development system. Service is activity or benefit offered by one party to another that is essentially intangible in characteristic and does not produce any ownership. The production may be tied or not tied to the physical product. Service is actually a performance of service, intangible, quickly lost, being more felt than owned and the consumers can participate actively in the process of consuming these services (Kotler, 1997). Demand of quality in education is the quality of knowledge and skills owned by educational personnel, especially the lecturers, dexterity in taking action, broad-minded, effectiveness of structural system in job organization and professional in handling duties. Meanwhile, the modern understanding of the quality of higher education is understood as conformity of productin nature with the needs of consumers.

For graduates, quality is the main problem to face competition. It will be achieved by improvement of service quality (SERVQUAL) provided by the institution. On management aspect, the process of higher education can be viewed as a continuous improvementstarting from a series of cycles since the idea to produce qualified graduates (output). Development of curriculum andlearning-teaching process has responsibility to satisfying the graduates (output). There are five determinations of service quality: (1) reliability is the ability to fulfillthe services precisely and reliably, (2) tangible is physical appearance referring to equipment and personnel as well as the communication medium (3) confidence or assurance is the ability to generate trust and confidence, (4) empathy is a care of giving attention to consumer, and (5) responsivenessis the willingness to help consumers and provide them with quick and responsive services (Kotler, 1997). Physical (tangible) service quality greatly affects the learning process and generallythe educational facilityis limited. The educational facility is generally provided adequately instate college, but very limited in private college, including books in library, laboratory, and the quantity and quality of lecturers are relatively limited. The purpose of this writing is to investigate, analyze and discover the dimensions of service quality, namely; reliability, physical appearance, assurance, empathy, and responsiveness affects customer satisfaction in private and state universities in Hail state. There are differences in service quality between the public and private colleges. 


\section{Literature Review}

Service characteristic is an intangible experience received by the consumer or customerin conjunction with the tangible product being purchased (Sienny, 2001). Service is categorized into two: (1) visible service, the service which can be seen and felt directly by consumers, provided by the provider who directly face the consumers and (2) invisibleservice,the services that cannot be seen and felt directly by consumers, these services support system visible. There are three main characteristics of service productwhich distinguish it from the retail product (Albert, 2002), namely, (a) Relative Intangible of Service, (b) Simultaneity of Service Production and Consumption, (c) Customer Participation.It is a dynamic condition relating to products and services. Additionally, quality is fitness for use. In various studies, since 1980s, service qualitytowards improvement of profitability was seen as something very important in encountering competition in business services, including public services. In literature, service quality (SERVQUAL) is often associated in relevance to large business organization with bureaucratic structures frequently leading to poor customer communications (Zeithami \& Bitner, 2003). Based on the literature, conceptualization of SERVQUAL has developed very rapidly since 1980 that began with the conceptualization (framework) by Grönroos (2000) named "the Nordic model". Another expert who is well known in the measurement of service quality and customer satisfaction is Zeithami \& Bitner (2003). They suspect that the perceived level of high service quality will generate customer satisfaction (Tufail et al., 2016).

Indicators of qualified lecturers are those who have academic reputations with the following characteristics; (1) the reputation of lecturers should be built on the accumulation of research results, scientific works and the quality of research result achievementsin the form of seminars: regional, national, and especially international scales; (2) possessing a specification on the substance of knowledge and expertise with a Master degree (S-2) and Doctoral (S-3) although still young; (3) not due to mere consideration of age seniorityand adequately long tenure, but the most important is the ability to develop themselves in accordance to the needs in times. Customer expectations is a key point for everyone who involved in customer satisfaction that Irwan (2002) states that without recognizing the customer's expectations as well as possible, it is very difficult for companies to be able to provide optimum satisfaction to its customers. Customers with high expectations will be difficult to make them satisfied and inversely customers with low expectations will be more easily to satisfy. Expectation is an estimate or belief of customers in what they will receive when buying or consuming a product or using a variety of services, while the perceived performance is what the customers really receive after consuming the products purchased or using services of a company Barnes (2003.)

Tse \& Wiltton (1988) expressed that satisfaction or dissatisfaction of customers is the response of customers to the evaluation of perceived mismatch between prior expectations and actual performance of the product being felt after use. Irwan (2002) argues that a satisfied customer is a customer who has gotten the manufacturer or service provider. This value may derive from product, service, system or something emotional. The concept of customer satisfactionis very diverse, as proposed Oliver (Cooper and Schindler (2006), with the expectancy disconfirmation models. In this model, the customer satisfaction is determined by cognitive variables, namely confidence in the anticipated result of a product or service and disconfirmation, i.e. the difference between expectations and reality, and the perception of pre purchase after purchase (post purchase perception). There has been a misunderstanding about the perception of satisfaction. The producers still consider the customer satisfaction lies in the price. They argued that if the price is low the consumer will satisfy. However, customer satisfaction lies in the quality of products and services in giving service. If customer satisfaction is created from the price, then the consumer gets immediate satisfaction. But in relation to quality, the long-term satisfaction should be created (Daft, 2003). Developed educational philosophy has been refracted into a sense of teaching with an emphasis on cognitive factors (recognition based on experience) and then the effective factor (internalization) and psychomotor (physical activity with respect to mental). Education in the broad sense can be defined as a process with a particular method that people acquiring knowledge, understanding and the way to behave in accordance with the needs of community (Sharma \& Patterson, 1999). 


\section{Methodology}

This research used quantitative method with two approaches: descriptive and explanatory. The descriptive approach was used to give explanation through the responses of respondents using tables, pictures and graphs of data collected descriptively and also be processed by others. The explanatory approach was used to explain thecausality, namely between the independent variables and the dependent variable. The independent variables: (X1) tangible, (X2) reliability, (X3) responsiveness, (X4) assurance, and (X5) empathy. The dependent variable is (Y) students' satisfaction in Hail. Data collection used (1) observation, (2) questionnaires, (3) interview and (4) documentation.

\section{Results}

Effect of Service Quality on Student Satisfaction: The result of this research after the test of validity and classic assumption stated thatthis research has satisfied to be analyzed by using multiple regression statistical analysis model. The remaining 0,629 or $62.90 \%$ is determined by other variables that are not included as researchvariables. The significance of students satisfaction improvement can be seen from the value of $\mathrm{F}_{\text {calculation }}=42,274$ and $\mathrm{p}(\mathrm{sig})=0,000<0,05$ being affected simultaneously by physical service (tangible), reliability, responsiveness, assurance and empathy. Thus, the research hypothesis is simultaneously proved significant. To know the effect of SERVQUAL variables of tangible, reliability, responsiveness, assurance and empathy on students' satisfaction in Hail state, the partial discussion is as follows.

(a) Effect of Tangible on Satisfaction: The level of student satisfaction received from the management of the four universities in Hail state can be seen from the value of R2 $=0.371$ or $37.10 \%$ that were influenced by an increase in satisfaction based on physical evidence as shown through standardized coefficientsunder the symbol of pi amounted to 0.090 or $9 \%$, with the assumption that the variables of service such as reliability, responsiveness, assurance and empathy in a constant state. The increase of student satisfaction was influenced by the increaseeffect of physical evidence that can be shown by the value $t=2.132$ and $p$ (sig) $0.034<0.05$. Thus, the hypothesis 1 sub $A$ is in partially proven that service quality (SERVQUAL) of physical evidence has positive and significant effect on student satisfaction during lecturing.

(b) Effect of Reliability on Student Satisfaction: The level of satisfaction the students received from the management of universities can be seen from the value of R2 $=0.371$ or $37.10 \%$ were influenced by the increase of student satisfaction based on reliability as shown by standardized coefficient with the symbol $\mathrm{p}_{2}$ of 0.093 or $9.30 \%$ on the assumption that the variablesof service quality (SERVQUAL) such as physical evidence, responsiveness, assurance and empathy are in constant state. Meanwhile, the significant increase in the level of student satisfaction was influenced by the increased influence of reliability that can be shown by the value $t=2.187$ and $p(\mathrm{sig}) 0.029<0.05$. Thus, Hypothesis $1 \mathrm{sub} b$ partially proven that quality service (SERVQUAL) through reliability of campus management services has significant and positive effect on the level of student satisfaction during the lecture.

(c) Effect of Responsiveness on Student Satisfaction: The level of student satisfaction received from the management of universities can be seen from the value of R2 $=0.371$ or $37.10 \%$ that were influenced by an increase in the contribution of satisfaction based on the responsiveness of service that can be indicated by standardized coefficientswith $\mathrm{p} 3$ symbol of 0.205 or $20.50 \%$ with the assumption that the other variablesof service quality(SERVQUAL) such as physical evidence, reliability, assurance and empathy were in a constant state. The significance of the increase in student satisfaction was influenced by the increase of the influence of responsiveness which can be shown by the value t count -4.742 and $p(\operatorname{sig}) 0.000<0.05$. Thus, the hypothesis 1 sub c is partially proven that quality service (SERVQUAL) through campus management service responsiveness was positively and significantlyaffect the level of satisfaction of the students during the lectures.

(d) Effect of Assurance on Student Satisfaction: The level of satisfaction the studentreceived from the management of universities can be seen from the value of R $=0.371$ or $37.10 \%$ that were influenced by an increase in satisfaction based assurance services that can be shown by standardized coefficientswith the 
symbol P4 of 0,118 or $18.80 \%$ with the assumption that the variable of quality of service (SERVQUAL) such as physical evidence, responsiveness, reliability and empathy were in constant state. The significant increase of student satisfaction was influenced by the increase in effect of the assurance as shown by the value $t=2.708$ and $\mathrm{p}$ (sig) $0.007<0.05$. Thus, the hypothesis $1 \mathrm{sub} d$ was partially proven that quality service (SERVQUAL) through assurance of campus management services has positive and significant effect on the level of student satisfaction during the lecturing in universities.

(e) Effect of Empathy on Student Satisfaction: Satisfaction of Management students can be affected by the service they get. Based on the results of this study that the validity and classic assumptionswas for the first tested, the data of all variables of this research are eligible to be analyzed using a model of statistical analysis regression through SPSS to find out briefly the difference between the level of students satisfaction who study at state universities and private higher universities. Based on the test results mentioned above, the second hypothesis of the research was received on the significant rate of $95 \%$. So,there is a difference in the level of satisfaction felt by students from both state and private colleges. Many factors that cause these differences, namely at state universities students are very adherent to meet their obligations on time, because of the better service(on time), especially in lecturing, the strict rules to make students attempting to fulfill their obligations on time. Meanwhile,the students at private universities frequently got service of lecturing irregularly making them dissatisfied.

Quality of service through responsiveness is also seen that there is a difference if the note of contribution between the responsiveness of the services provided by the universities run by the government and universities managed by foundations or private. Based on the statistical results showed that the quality of empathy services shown by colleges by the second government has diferent with colleges by the second foundation. The difference between public and private universities can. In addition to supporting the research of Tjiptono, other evidence that shows how much attention of many researchers to customer satisfaction seen from the many results of research conducted Among done at PT. Jamsostekby Setyanto (1999), which examines the quality of service as perceived by subscribers on the three branches of Social Security, namely Publications, Darmo and Tanjung Perak in Surabaya with the finding that the five dimensions of quality of services which include: direct evidence, reliability, responsiveness, assurance and empathy can affect customer satisfaction. Then Kadir (2001) in her dissertation tried to examine the effect of the bank's management commitment to the level of employee satisfaction and customer satisfaction rate of banks in South Sulawesi. The results showed there were differences in the level of customer satisfaction, for example, the dimensions of tangible commercial banks government considered more satisfactory than private banks, on the contrary dimension realibity private banks considered more satisfactory by customers when compared to state-owned commercial banks.

Another researcher, Daft (2000), examined the impact of service quality on customer behavior taxi transport services which concludes the influence between service quality and customer behavior that is favorable or unfavorable. Behavior that is favorable to say positive things about the service providers, include: recommending to another prospect, remain loyal to the company, re-purchase or pay a premium price. While the favorable behavior indicates otherwise.Thus, this study further strengthens the findings of previous studies, although this study used different objects with variables that are relatively the same but with a different indicator. Research can provide new nuance in the development of science, especially in terms of quality of service.

Discussion of Partial Effect: The discussion of partial effect was intended to find out and get a more specific description of each of the variables studied. The findings of each variable of the service qualitywill make it easier to find the cause of the weakness or strength in the service of each independent variable on the dependent variable. The findings of effect of each independent variable on dependent variablewill make easier to know the cause the effect rises and falls.

(a) Effect of Reliability on Student Satisfaction: The service quality from the dimension of reliability includes the on-time lecturing process, student assignments, examination, administrative services, feedback of students' works. The fifth indicators of reliability variable used to the universities, both the public and private were still not optimal. It isproved by the contribution valueto the level of student satisfaction at only 
0.093 or only $9.30 \%$. The low quality of service reliability is also triggered by differences in reliability services, where the public universities are relatively more reliable in service compared with private universities with the different contributions that the state collegewas larger (18.10\%)than the private colleges $(13.20 \%)$. The difference due to the state colleges having more capable employees than the private colleges with various limitations.

(b) Effect of Responsiveness on Student Satisfaction: Service quality from the dimensions of responsiveness includes the readiness to listen to the complaints given by students, responsiveness to deal rapidly with the complaints of students, the readiness and ability to explain the procedures and systems concerning the lecturing the students do not yet understand, and creativity in solvingthe problems faced by students. The four indicators of responsiveness variables were valid for all universities, but still not in accordance with the expectations of most students. This can be evidenced by the value of its contribution to the level of student satisfaction at only 0.205 or only $20.50 \%$. The low service quality of responsiveness is also triggered by the difference in responsiveness service, where state universities are still relatively more responsive in service to students than in private universities with different contributions that the state university is bigger, namely $29,30 \%$ that the private university only reaches $12,80 \%$. The differences in service quality of responsiveness is caused bystate colleges having a number of professional and competent employees in providing better services. The dimension of responsiveness which needs improvement is responsive to student complaints. In this regard, three possibilities that occur in connection with their level of satisfaction: customers satisfy to action taken for overcoming their problem (Irwan, 2002).

(c) Effect of Assurance on Student Satisfaction: The service quality of assurance dimensions in the form of lecturer professionalism, ability to solve the problems faced by students, ensure the security and safety of the vehicle and student facilities, ensure the safety of students during staying in college, ensure that no illegal payments were made by either lecturer, administrative and even students itself. The fifth indicators of the quarantine variable are valid for universities organized by both the government and the private and it does not prove to satisfy the expectation. With the difference in the background, private colleges are able to understand the difference in providing services compared with thin comparison with a college run by the government using various limitations. Results of this research have supported the research conducted by Tjiptono (2003), who found that the service quality of empathy has effect on students' satisfaction. This research further contributes to the research result in this field of service quality, especially in the service of empathy.

\section{Conclusion}

Based on the discussion of research results having been stated previously, the general conclusion is that there is a positive and significant simultaneous effect of service quality (SERVQUAL) between physical service (tangible) and reliability, between physical service (tangible) and empathy to students' satisfaction at the universities in Saudi Arabia. The partial effect of the five dimensions of SERVQUAL as dependent variables is concluded as follows:

- Physical service (tangible) has positive and significant effect on the level of student satisfaction at the universities in Hail state.

- Reliability has positive and significant effect on the level of student satisfaction at the universities in Hail state.

- Responsiveness has positive and significant effect on the universities in Hail state.

\section{References}

Albert, C. (2002). Service loyalty: The effects of service quality and the mediating role of customer satisfaction. European Journal of Marketing, 36(7/8), 811 - 828

Barnes, J. G. (2003). Secrets of Customer Relationship Management. It's all About How You Make Them Feel. New York: McGraw-Hill

Cooper, L. \& Schindler, F. (2006). Business Research Methods, New York: McGraw-Hill

Daft, R. L. (2003). Manajemen Sumber Daya Manusia. Jakarta: Erlangga. 
Gronroos, C. (2000). Service Management and Marketing: A Customer Relationship Management Approach, $2^{\text {nd }}$ edition, Chichester: John Willey \& Sons, Ltd

Irwan, H. (2002). 10 prinsipke puasanpe langgan, cetakan Kedua, PT. elex Media Komputindo, Jakarta.

Kadir, A. R. (2001). Pengaruh Komitmen Manajemen Bank terhada ptingka tkepuasan Kerja Karyawandan Tingkat Kepuasan Nasabah Bank di Sulawesi Selata. Disertasiti dakdipubli kasikan, Program Pasca SarjanaUniversitas Airlangga, Surabaya.

Kotler, P. (1997). Manajemen Pemasaran, Analisis Perencanaan, Implementasi, dan Kontrol, Edisi Sembilan Terjemahan, PT. Phenhallindo, Jakarta

Sharma, N. \& Patterson, P. G. (1999). The impact of communication effectiveness and service quality on relationship commitment in consumer, professional service. Journal of Service Marketing, 13(2), 151170

Sienny, T. (2001). Membangun Service Quality Untuk Mencapai Kepuasan Konsumen di Industri Hospitality

Tse, D. K. \& Wiltton, P. C. (1988). Model of Consumer Satisfaction Formation; A Extension. Journal of Marketing Research, 25, 12-24

Tufail, M. S., Muneer, S. \& Ishtiaq, M. (2016). Job Characteristics with Task and Contextual Performance: Moderating Role of Procedural Justice for Front Line Managers. Journal of Social Sciences, Special Issue, 299-508.

Daft, R. (2000). Manajemen. Edisikelima. JilidSatu. PT Gelora Aksara Pratama (Erlangga). Jakarta.

Tjiptono, F. (2004). Strategi Pemasaran. EdisiKedua. Andi Offset, Yogyakarta.

Setyanto (1999). Researchers to customer satisfaction seen from the many results of research conducted among done at PT. Jamsostek.

Zeithaml, V. A. \& Bitner, M. J. (2003). Service Marketing, McGraw-Hill, New York. 